\title{
ГЭМТ ХЭРГИЙН СТАТИСТИК ЗУЙН ОНОЛ, ПРАКТИКИЙН ТУЛГАМДСАН АСУУДАЛ
}

\author{
Б.Мөнхдорж
}

Хууль сахиулахын их сургуулийн Эрдэм шинжилгээ, хөгжлийн хүрээлэн, Монгол улс Цахим шуудан: b.munkhdorj@gmail.com

\section{ХУРААНГУЙ}

Гэмт хэргийн статистик зүй гэдэг нь шинжлэх ухааны үндэслэлтэй зохион байгуулсан програмаар, гэмт хэргийн талаарх тоо бүртгэл хөтлөх, иуглуулах, боловсруулах, түүнд судалгаа, иинжилгээ хийж, гэмт хэргийн тоон мэдээллий шалтгаан нөхиөл, шинж чанартай нь уялдуулан тодорхой орон зай, цаг хугаиаанд судалдаг салбарын статистик гэж тодорхойлж болох юм. Үүний практик хэрэглээ нэн чухал юм. Монгол Улсад гэмт хэргийн статистикийн тогтолиоо оновчтой бус, иагдаа, авлигатай тэмиэх, шүүхийн шийдвэр гүйщэтгэх, прокурорын байгууллага болон шүүхийн гэмт хэрэг, зөрчлийн тоо бүртгэл, арга зүй уялдаагүй, гэмт хэрэг, зөрчлийн тоо бүртгэлийн аргачлал, нэгдсэн статистик мэдээлэлгүй байна. ҮҮнээс ҮҮдэн гэмт явдлын тоо бүртгэл бодитой бус байгаа нь төрөөс гэмт хэрэгтэй тэмиэх бодлогод үр дүнтэйгээр нөлөөлж чадахгүй байна.

Гэмт хэргийн статистикийн талаар онолын судалгаа хийж, судалгааны үндсэн дээр үзэл баримтлал, онолын үндэслэл боловсруулах, эрдэм шинжнлгээний бүтээл эрхлэн гаргах, өгүҮлэл нийтлҮүлэх, цагдаа, авлигатай тэмиэх, прокурор, шүҮх, шүҮхийн шийдвэр гүйцээтгэх байгууллагын гэмт хэргийн бүртгэлийн болон статистикийн мэдээний маягтыг шинэчлэх, програм хангамж, мэдээлийн системийг боловсронгуй болгох санал боловсруулах, холбогдох баримт бичигт нэмэлт, өөрчлөлт оруулах зэрэг тулгамдсан асуудал байна.Цааиид гэмт хэргийн статистикийн үйл ажиллагааг зохииуулсан эрх зүйн орчинг боловсронгуй болгох, холбогдох хууль тогтоомжид нэмэлт, өөрчлөлт оруулах, гэмт хэргийн статистикийн үндэсний хэмжээний аргачлалыг бий болгож мөрдүүлэх, гадаадын зарим улсын эрх зүйн зохииуулалт, олон улсын байгууллагын шийдвэр, стандартыг харьиуулан судлах шаардлагатай байна. Улмаар гэмт хэргийн статистик зүй нь хавсарга шинжслэх ухаан хэмээн үзэж, түҮний боловсронгуй болгох талаарх дүгнэлт, санал дэвщүүлэв

Түлхүур үгс: Статистик, гэмт хэрэг, гэмт явдал судлал, гэмт хэргийн статистик

\section{ОРШИЛ}

ЭнэХүҮ өгүүллийг бичихдээ гэмт эрдэм шинжилгээний илтгэл, өгүүллийг хэргийн статистиктай холбоотой эрдэм судалсан болно. Түүнчлэн, Монгол Улсын шинжилгээ, судалгааны үр дүн, бүтээл, цагдаа, авлигатай тэмцэх, шүүхийн шийдвэр 
гүйцэтгэх, прокурор, шүүх, статистикийн байгууллагын үйл ажиллагаанаас гэмт хэрэгтэй холбоотой статистик мэдээлэл эрхлэн гаргаж буй үйл ажиллагаанд дүн шинжилгээ хийв. Судалгааг явуулахад нэгтгэн дүгнэх, задлан шинжлэх, баримт бичиг, системийн дүн шинжилгээ хийх зэрэг шинжлэх ухааны түгээмэл аргыг ашиглав.

Криминологи, эрүүгийн эрх зүй, цагдаа судлал, шинжлэн магадлахуй судлал, гэмт хэрэг илрүүлэхүй, математик, статистикийн шинжлэх ухааны уялдаа холбоо, гэмт хэргийн статистикийн онолын үзэл баримтлал, ойлголтыг авч үзэхийн зэрэгцээ гэмт хэргийн статистикийн өнөөгийн тогтолцоо, эрх зүйн зохицуулалтыг судалж, дүгнэлт хийлээ. Гэмт хэргийн статистикийн онол, арга зүй магистрын түвшинд хэрхэн судлагдсан байдлыг түүвэрлэн гаргаж судалсан болно. Судалгааны ажилтай

\section{СУДЛАГДСАН БАЙДАЛ}

Гадаадын зарим орны туршлагаас үзэхэд Crime statisticis, Mathematics, Statistics and the Law, Criminal Justice statistics, Crime and mathematics, Quantitative Criminology, Statistics for Criminology and Criminal Justice, Уголовная статистика, Юридическая статистика, Правовая статистика, Судебная статистика гэх мэт чиглэлээр асуудлыг судалж байна. Тухайлбал, ОХУ-ын эрдэмтэн Ю.Д.Блувштейн математик ба криминологи, АНУ-ын Дэвид Грийнберг зэрэг эрдэмтэн математик, магадлал, статистикийн шинжлэх ухааны арга зүйг гэмт хэргийг судлах, криминологийн шинжлэх ухаанд ашиглах талаар судалсныг цаашид гүнзгийрүүлэн судлах шаардлага байна. Олон улсын мэргэжлийн сэтгүүлд нийтлүүлж буй эрдэм шинжилгээний өгүүлэлд судалгааны үр дүнг тооцоход математик, статистикийн арга зүй, загварчлалыг өргөнөөр ашиглах болсоноос үзэхэд гэмт явдлыг судлахад математик, холбогдуулан гадаадын эx сурвалжыг харьцуулан судлав. Энэхүү судалгааны ажлын шинэлэг тал нь математик, статистикийн аргачлалыг ашиглан гэмт хэргийн статистикийг онолын түвшинд хөгжүүлэх, тогтолцоог сайжруулах, мэдээллийн үнэн бодит байдлыг хангах чиглэлээр тодорхой санал, зөвлөмж дэвшүүлсэнд оршино.

Криминологи, эрүүгийн болон эрүүгийн процессын эрх зүй, шинжлэн магадлахуй, шүүхийн шийдвэр гүйцэтгэх, цагдаагийн эрх зүй, криминалистик, математик, магадлал, статистик, социологи, мэдээллийн технологи зэрэг салбарын шинжлэх ухаантай ямар зүй тогтолт уялдаа холбоонд оршдогийг авч үзэхийн зэрэгцээ гэмт хэргийн статистикийн тогтолцоо, эрх зүйн зохицуулалтад дүн шинжилгээ хийж, түүнийг боловсронгуй болгох онол, практикийн асуудлыг судлахад оршино. статистикийн шинжлэх ухааны ач холбогдол улам бүр нэмэгдэж байна. Ю.Д.Блувштейн риминилоги Сүүлийн үед өгөгдөлд дүн шинжилгээ хийх, нийгэм, эдийн засгийн үзэгдлийг дата өгөгдөлд математик статистикийн арга, $\mathrm{R}$ програм хангамжийг ашиглах, дүгнэлт хийх зэрэг арга зүйг эрчимтэй ашиглах хандлагатай байна.

Гэмт хэргийн статистикийн онол, арга зүй олон оронд эрчимтэй хөгжиж байгаа боловч Монгол Улсад 1988 онд Я.Баатар, Д.Тархаашин “Гэмт хэрэг судлах статистик арга зүй”, 2007 онд П.Ихзаяа, С.Жанцан, Б.Мөнхдорж "Гэмт хэргийн статистик" нэг сэдэвт бүтээлээс өөр дагнан судалсан эрдэм шинжилгээний бүтээл хомс байгаа нь гэмт хэргийн статистикийн онол, арга зүйг тодорхойлсон бүтээл үгүйлэгдэж байгааг харуулж байна. Математик, статистикийн арга, арга зүйг гэмт явдлыг судлахад ашиглах талаар Монголын эрдэмтэн, 
судлаачид 20 гаруй эрдэм шинжилгээний өгүүлэл нийтлүүлж, илтгэл хэлэлцүүлжээ. Гэмт хэргийн статистикийн онол, арга зүйг практик үйл ажиллагаанд нэвтрүүлэх, ашиглах талаар 2005 оноос хойшх хугацаанд МУБИС, ХУИС, ХААИС-д магистрын судалгааны дөрвөн ажил хийгджээ.

Монгол Улс дахь гэмт хэргийн байдал, түүний шалтгаан нөхцөл, түүнээс урьдчилан сэргийлэх талаар 2006 оноос эхлэн Цагдаагийн ерөнхий газраас бүртгэгдсэн гэмт хэрэг, захиргааны зөрчил, цагдаагийн байгууллагын үйл ажиллагаанд үндэслэн жил бүр гаргаж ирсэн нь сайшаалтай байна. Энэ нь олон улсын жишиг, шаардлагад нийцэхгүй, зөвхөн цагдаагийн байгууллагын хэмжээнд бүртгэгдсэн гэмт хэрэг, зөрчлийн статистик мэдээлэлд үндэслэгдсэн байдал зэрэг нь дутагдалтай хэмээн үзэж байна. Дэлхийн олон улсад гэмт хэргийн байдалд тал бүрээс нь иж бүрэн дүн шинжилгээ хийсэн "Гэмт хэргийн цагаан ном буюу White paper on crime book"-ыг жил бүр тухайн улсынхаа онцлогт нийцүүлэн гаргаж байна. Тухайлбал, Япон улсад гэмт хэргийн статистикийн хэрэглээ боловсронгуй болж хөгжсөн нь жил бүр эрхлэн гаргадаг гэмт хэргийн цагаан номоос харагддаг. ХБНГУ ч гэсэн гэмт хэргийн цагаан номыг герман, англи хэлээр гарган, нийтийн хүртээл болгож байна. [1]

Монгол Улсад гэмт хэргийн статистик, түүний онол, практик, хэрэглээг боловсронгуй болгох чиглэлээр дагнасан онолын судалгааны ажил, бүтээл үгүйлэгдэж байгаагаас үзэхэд онолын түвшинд асуудлыг гүнзгийрүүлэн судлах шаардлагатай байна.

\section{Криминологи, статистикийн шинжлэх ухааны уялдаа}

Хүн төрөлхтөн гэмт явдлаас учрах аюул, заналхийллийн хүрээнд амьдарч ирсэн, одоо ч амьдарсаар байна. Нийгмийн сөрөг үзэгдэл болох гэмт явдлыг хүн төрөлхтөн олон жил таньж мэдэхийг оролдон, түүний шалтгаан нөхцлийн талаар янз бүрийн онол, үзэл баримтлал боловсруулж, гэмт хэргээс урьдчилан сэргийлэх оновчтой арга замыг эрэлхийлсээр ирсэн билээ. [2] Гэмт явдалтай тэмцэх арга замыг янз бүрийн түвшинд эрэлхийлж судалсаар байна. Криминологийн шинжлэх ухаан нь гэмт явдлын шалтгаан, нөхцөл, гэмт хэрэгтний хувийн шинж төрх, онцлогийг судалж, урьдчилан сэргийлэх арга хэмжээг боловсруулдаг. [3]

Гэмт хэргийн шалтгаан нөхцөлийг судлах асуудал онолын түвшинд баяжиж, улам боловсронгуй болж байгаа хэдий ч түүнийг практикт нэвтрүүлэх, үр дүнг ашиглах явдал хангалттай бус байна. Криминологийн шинжлэх ухаан бол гэмт явдал, гэмт явдлын шалтгаан, нөхцөл, гэмт хэрэгтний хувийн шинж, төрх, гэмт явдлаас урьдчилан сэргийлэх арга хэмжээ буюу бодлого, гэмт хэргээс учирсан хор хохирол зэргийг судалдаг. Криминологи гэдэг нь латин гаралтай “Crimen”-гэмт хэрэг, грек гаралтай “Logos”-судлал, сургаал гэсэн агуулгыг нэр томьёоны хувьд илэрхийлдэг. Дэлхийн улсуудад криминологийн шинжлэх ухааны шинэ хандлага, төрөл бий болж хөгжиж байна. Тухайлбал, нийтийн криминологи (public criminology), хүн судлалын криминологи, хүрээлэн буй орчны криминологи (environmental criminology) зэргээр салбарлан хөгжиж байна. Криминологийн шинжлэх ухааны судлах зүйлийн үндсэн хэсэг болох “гэмт явдал" нь нийгмийн сөрөг үзэгдэл бөгөөд тодорхой цаг хугацаанд улсын хэмжээнд болон тодорхой бүс нутаг дэвсгэрт үйлдэгдсэн гэмт хэрэг, захиргааны зөрчлийн нийлбэр цогц гэж ойлгож болно.

“Криминологи” гэдгийг олон улсад гэмт явдалтай тэмцэх үйл ажиллагааг судалдаг шинжлэх ухаан хэмээн үзэж, хууль боловсруулах, хууль сахиулах тогтолцоо, тэдгээрийг хэрэгжүүлэх үйл ажиллагааг хамруулсан өргөн хүрээнд ойлгож, томьёолдог. Гэмт явдал судлал [4] гэдэг нь гэмт хэрэг болон гэмт хэрэгтнийг судалдаг 
тусгай шинжлэх ухаан мөн. Судлаач Эдвин Сутерланд [5] "Гэмт явдал судлалын зарчим (1939)” хэмээх номондоо бичсэнээр: “Гэмт явдал судлал нь гэмт хэргийг нийгмийн үзэгдэл хэмээн авч үздэг мэдлэгийн хэлбэр юм. Тухайн ойлголт нь өөрийнхөө хүрээнд хууль боловсруулах, хууль зөрчих болон хууль зөрчсөн үйлдэлд хариу үзүүлэх явдлыг хамруулдаг байна" гэжээ.

Гэмт явдал нь гэмт хэргээс илүу өргөн хүрээний ойлголт юм. "Гэмт явдал” (англиар-criminality, оросоорпреступность) ял оногдуулахаар Эрүүгийн хуульд заасан, эрх зүй зөрчсөн, бодитой үйлдэгдэн гарсан бүх гэмт хэргийн нийлбэр цогц, түүнчлэн тодорхой зүй тогтолтой тооны ба чанарын шинж бүхий нийгмийн эрх зүйн нийт сөрөг үзэгдлийг илэрхийлсэн криминологийн ухагдахуун юм. [6] "Гэмт явдал нь нийгмийн хөгжлийн явцад улс төр, эдийн засаг, үзэл суртал, ёс суртахууны хүрээнд үүссэн элдэв гажуудал, зөрчил, сөрөг үзэгдлийн шууд үр дагавар болж, тооны буюу чанарын үзүүлэлтээр илэрхийлэгддэг өөрийн зүй тогтолтой, нийгэм эрх зүйн үзэгдэл юм. Гэмт явдал нь тодорхой гэмт хэргүүдийг өөртөө багтаасан цогц ойлголт юм" гэж тодорхойлсон байна.

Эрүүгийн хуулийн 16 дугаар зүйлд “Эрүүгийн хуульд эрүүгийн хариуцлага хүлээлгэхээр заасан, нийгэмд аюултай гэм буруутай үйлдэл, эс үйлдэхүйг гэмт хэрэг гэнэ” [7] гэж заасан. Гэмт явдал бус, зөвхөн гэмт хэргийн статистикийн хүрээнд судалгааны ажлын хэмжээ хязгаарыг тогтоосон болно.

Гэмт явдлын тооны болон чанарын харилцааг гэмт явдлын түвшин, хөдөлгөөн, бүтэц гэсэн гурван үндсэн үзүүлэлтээр илэрхийлэн судалдаг. Гэмт явдлын түвшин гэдэг нь түүний тоон үзүүлэлт бөгөөд өөрөөр хэлбэл, тайлант хугацаанд тодорхой нутаг дэвсгэрт үйлдэгдсэн гэмт хэрэг, зөрчлийн тоон үзүүлэлт юм. Үүнд мөн нуугдмал гэмт хэргийг авч үзэх нь зүйтэй. Гэмт явдлын түвшинг тооцоолоходоо хууль сахиулах байгууллагад бүртгэгдсэн гэмт хэргийн албан ёсны тоогоос гадна нуугдмал гэмт хэргийн түвшинг давхар тооцож үзэх нь нэн чухал. [8] Гэмт явдлын хөдөлгөөн гэдэгт гэмт хэрэг, зөрчлийн өсөлт, бууралтыг ойлгож болно. Тухайлбал, өмнөх онуудтай, эсвэл өмнөх оны мөн үеийн түвшинтэй, өмнөх саруудын түвшинтэй харьцуулах замаар гэмт хэрэг, зөрчлийн хөдөлгөөнийг илэрхийлж, өссөн, буурсан талаарх тоон үзүүлэлтийг гаргадаг. Гэмт явдлын бүтэц гэдэгт гэмт явдлын төрөл, ангилал, зарим онцлогийг хамруулан ойлгож болно. Тухайлбал, гэмт хэргийн төрөл, үүнд хулгайлах, бусдын бие махбодид гэмтэл учруулах, танхайрах, замын хөдөлгөөний аюулгүй байдлын эсрэг зэрэг гэмт хэргийн тоо, тэдгээрийн эзлэх хувийн жинг харуулдаг. Гэмт хэрэг үйлдэгдсэн зарим онцлогийн тухайд насанд хүрээгүй болон эмэгтэй хүмүүс оролцсон, архидан согтуурсны болон гэр бүлийн хүчирхийлэл, маргааны улмаас, мөн бүлгээр, галт зэвсгээр үйлдэгдсэн гэмт хэргийн тоо, тэдгээрийн хувийн жин, хөдөлгөөнийг харуулж болно.

Эрүүгийн хуульд зааснаар 223 гэмт хэргийг хуульчлан тогтоосон. Өнөөдөр гэмт хэрэг дотроос бусдын бие махбодид гэмтэл учруулах, хулгайлах, танхайрах, замын хөдөлгөөний аюулгүй байдлын эсрэг, булаах, дээлэмдэх, залилан мэхэлж авах, хүний амь насыг хохироох, хүчиндэх зэрэг тодорхой 8-9 төрлийн гэмт хэрэг голлон үйлдэгдэж, эдгээр нь нийт гэмт хэргийн 80-90 орчим хувийг эзэлж байна. Орчин үед “гэмт хэрэгтэн”-тэй зэрэгцүүлэн “хохирогч"-ийн талаарх мэдээллйг цуглуулах, дүн шинжилгээ хийх, нэгтгэн дүгнэх нь урьдчилан сэргийлэх ажлын чиглэлийг оновчтой тодорхойлох, халдлагад өртөмтгий хүмүүсийн бүлэг, төрлийг олж тогтоон, тэдэнтэй ажиллах шаардлага гарч байна.

Криминологийн шинжлэх ухаантай зэрэгцээд гэмт хэргийн хохирогч, түүний нийгэм, хүн ам зүйн шинж, гэмт хэргийн хохирогчийн зан байдал, гэмт хэрэгтэн 
ба хохирогчийн харилцан хамаарал, гэмт хэрэгт хохирох эрсдэл, хохирлын төрөл, түүний үр дагаврын талаар судалдаг виктимологийн шинжлэн ухаан хөгжиж байна.[9] Өмнө нь гэмт хэргийн улмаас хохирсон хохирлын мэдээлэл гардаг байсны дээр цагдаагийн байгууллага 2007 оноос эхлэн гэмт хэргийн халдлагад өртөж хохирсон иргэн, хуулийн этгээдийн талаарх мэдээллийн сан бүрдүүлж байна.

Нийгэм, эдийн засгийн үзэгдлийн тоо мэдээллийг цуглуулах, боловсруулах, задлан шинжлэх, нэгтгэн дүгнэх арга зүйн суурь шинжлэх ухааныг статистик хэмээх ойлголт түгээмэл болсон. “Статистик”[10] хэмээх нэр томъёо нь "status" гэсэн латин үгнээс гаралтай юмс үзэгдлийн төлөв байдал гэсэн утгатай үг. Орос хэлнээс “статистик” гэдэг нь “тоо бүртгэгч, статистикч”, “статистика” гэдэг нь “тоо бүртгэлийн шинжлэх ухаан, статистик, тоо бүртгэл" гэж монгол хэлээр орчуулжээ.[11]

Я.Цэвэлийн “Монгол хэлний товч тайлбар толь”[12] “тооны бүртгэл” гэдгийг “бүртгэл, тооцоо, тооллого, малын тоо бүртгэл, хүн амын бүртгэл”, “тоо бүртгэлийн судлал” гэдгийг “нийгмийн хөгжил, ардын аж ахуй дахь тооны хуваарилалтыг судлах ухаан”, “тоо бүртгэгч” гэдэг нь “тоо бүртгэл эрхэлсэн хүн”, “зүй” гэдэг нь “...ямар нэгэн сургаал, онол, арга зүй” гэж тус тус тайлбарлажээ. Иймд гэмт хэргийн статистикийг онолын түвшинд судалж, хөгжүүлэх шинжлэх ухааны нэршлийг “гэмт хэргийн статистик зүй”" гэмт хэргийн статистик гэж томьёолохыг санал болгож байна. Шинжлэх ухаан [13] гэдэг нь шинжлэх ухааны судалгааны арга дээр тулгуурласан мэдлэгийн цогц ба судалгааны үр дүнгээр гарган авсан, зохион байгуулалтад оруулсан мэдлэг юм.

Олон улсын хэмжээнд нийтлэг мөрддөг тодорхойлолтоор: “Статистик нь нийгэм, эдийн засгийн тоон мэдээллийг цуглуулах, дүн шинжилгээ хийх, үр дүнг тайлбарлах, танилцуулахтай холбоотой шинжлэх ухаан юм” гэж тодорхойлсон байдаг. Монгол
Улсын хувьд “Статистик нь нийгэм, эдийн засгийн юмс үзэгдлийн тоон илрэлийг чанартай нь холбон тэдгээрийн хөгжлийн зүй тогтлыг тодорхой орон зай, цаг хугацаанд судалдаг шинжлэх ухаан юм" хэмээн ойлгож болно. Зарим статистикийн судлаач “статистик бол үр ашигтай шийдвэр гаргахад шаардлагатай тоон мэдээллийг цуглуулах, боловсруулах, нэгтгэн дүгнэх, дүн шинжилгээ хийх, тайлбарлах, танилцуулах арга зүйн тухай шинжлэх ухаан" гэж тодорхойлж байна. Нийгэм, эдийн засгийн Үзэгдэл, процессын тоо мэдээллийг шинжлэх ухааны үндэстэйгээр цуглуулж, боловсруулан шинжилгээ хийж, түүний зүй тогтол, харилцан хамаарлыг тооны аргаaр нээж үнэлэлт, дүгнэлт гаргадаг шинжлэх ухааныг статистик [15] гэж эрдэмтэн, судлаачид тодорхойлжээ.

Хүн төрөлхтөн хийж бүтээсэн баялаг, өмч хөрөнгө, мал, хэрэглэж буй эд зүйлээ бүртгэн тооцоолох зайлшгүй шаардлагаар амьдрал дээр статистик НТӨ 2200-аад оны үед эртний Вавилон, Египед, Ромд үүссэн байдаг. Практик статистик 4000 гаруй жилийн түүхтэй байхад онолын статистик сүүлийн 300 гаруй жилийн хугацаанд үүсэн эрчимтэй хөгжиж байна. Монгол Ардын Намын III их хурал, Улсын Анхдугаар Их Хурлаас 1924 онд тоо бүртгэлийн хэлтсийг байгуулан улсын тоо бүртгэлийн ажлыг эрхлэх үүргийг хариуцуулсан үеэс эхлэн Монгол Улсын Статистикийн алба хөгжих үндэс суурийг тавьжээ. 2015 онд Улсын бүртгэл, статистикийн ерөнхий газар болж, 2016 оноос Үндэсний статистикийн хороо нэрээр үйл ажиллагаа явуулж байна.

Статистикийн шинжлэх ухааны судлах зүйл нь нийгэм, эдийн засгийн юмс, үзэгдлийн тоо мэдээллийг чанарын агуулгатай нь нягт холбоотойгоор тодорхой орон зай (улс, тодорхой бүс нутаг), цаг хугацаанд судлах явдал байдаг. Статистикийн юмс, үзэгдэл нь статистикийн хэмжигдэхүүнээр тодорхойлогддог. Статистикийн хэмжигдэхүүн гэдэг нь судалж буй юмс, үзэгдлийн шинж чанарын 
тоон үнэлгээ юм. Статистикийн шинжлэх ухааны аргыг гүйцэтгэх үүргийг нь харгалзан боловсруулалт, шинжилгээний гэсэн хоёр бүлэгт хуваадаг.

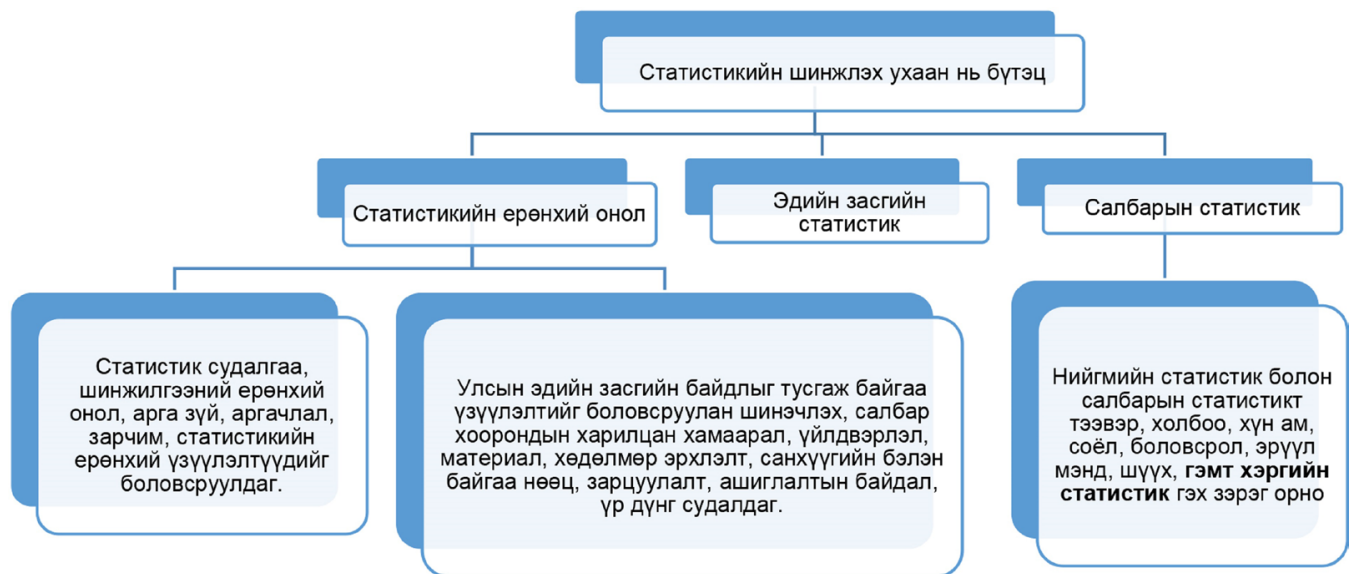

Зураг-1. Статистикийн шинжлэх ухааны бүтэи

Хүснэгт-1. Боловсруулалт, шинжилгээний аргуудын бүлэглэл

\begin{tabular}{|c|c|}
\hline Боловсруулалтын бүлэгт: & Шинжилгээний бүлэгт: \\
\hline $\begin{array}{ll}\text { • } & \text { Тоо мэдээллийг бүлэглэлт, товчоололт } \\
& \text { хийх; } \\
\text { • } & \text { Тархалтын цуваа байгуулах; } \\
\text { • } & \text { Статистик хүснэгт зохиох; } \\
\text { • } & \text { График дүрслэлээр илэрхийлэх; } \\
\text { • } & \text { Үзүүлэлтүүдийг харьцуулах, зэрэгцүүлэх; } \\
\text { • } & \text { Дундажлах, нийлбэрийг тооцох; } \\
& \text { ҮзүлэлтүҮдийн хэлбэлзлийг тооцох зэрэг } \\
& \text { аргауудыг }\end{array}$ & $\begin{array}{ll}\text { • } & \text { Динамик эгнээний шинжилгээ; } \\
\text { • } & \text { Нөлөөлж буй хүчин зүйлсийн корреляцийн } \\
& \text { шинжилгээ; } \\
\text { • } & \text { Регрессийн шинжилгээ; } \\
\text { • } & \text { Түүвэр судалгааны арга; } \\
\text { • } & \text { Дисперси; } \\
\text { • } & \text { Индекс; } \\
\text { - } & \text { Магадал таамаглал дэвшүүлэх зэрэг } \\
& \text { аргаууд }\end{array}$ \\
\hline
\end{tabular}

Статистик нь задлан шинжлэх (анализ), нэгтгэн дүгнэх (синтез), хийсвэрлэх (абстракт), түүхчлэх, ерөнхийгөөс тодорхой, тодорхойгоос ерөнхийд хандах зэрэг шинжлэх ухааны түгээмэл аргыг шууд баримтална. Статистикийн арга зүй гэдэг нь нийгэм, эдийн засгийн бүтэц, динамик болон хамаарлын зүй тогтлыг судлахад чиглэгдсэн арга, аргачлалын тогтолцоо юм. Энд математик статистикийн шинжлэх ухааныг дурдахад санамсаргүй үзэгдлийг ажиглах явцад гарган авсан туршилтын статистик тоон мэдээллийг бүртгэх, цуглуулах, судлах, шинжилгээ хийх аргыг боловсруулдаг шинжлэх ухааныг математик статистик гэнэ [16].
Гэмт явдал судлал, эрүүгийн болон эрүүгийн процессын эрх зүй, шинжлэн магадлахуй, шүүхийн шийдвэр гүйцэтгэх, цагдаагийн эрх зүй, криминалистик, математик, магадлал, статистик, социологи, мэдээллийн технологи зэрэг шинжлэх ухаантай уялдаатайгаар гэмт хэргийн статистикийн онол, арга зүйг боловсронгуй болгож, оновчтой тогтолцоо, эрх зүйн зохицуулалтыг төлөвшүүлж, статистикийн мэдээллийг үнэн зөв, бодитой болгох замаар гэмт хэрэгтэй шинжлэх ухааны үндэслэлтэйгээр тэмцэх явдал юм. 


\section{Гэмт хэргийн статистик зүйн онолын зарим асуудал}

Нийгмийн сөрөг үзэгдэл болох гэмт хэрэг нь гаралт, хөдөлгөөн, тархац, бүтцийн хувьд байнга хувьсан өөрчлөгдөж байдаг. Олон улсын практикаас судалж Үзэхэд, хууль зүйн статистикийг эрүүгийн, шүүхийн, иргэний, захиргааны эрх зүйн статистик гэж ангилдаг. Тэгэхээр манай улсад хууль зүйн статистикийн илүү өргөн хүрээнд судлан үзэх шаардлага улам бүр нэмэгдэж байгаа ба эрүүгийн буюу гэмт хэргийн статистикийг нарийвчлан авч үзэх нь зүйтэй.

Гэмт хэргийн талаарх статистик ажиглалт хийж, мэдээлэл цуглуулах, боловсруулах, түүнд судалгаа, шинжилгээ хийж, хууль сахиулах, шүүх эрх мэдлийн байгууллага, алба хаагчдын ажлыг дүгнэх, удирдлагыг мэдээллээр хангах, гэмт хэргийн байдал, шалтгаан нөхцөлийг тодорхойлоход зайлшгүй статистикийн шинжлэх ухааны арга, аргачлал, арга зүйг үйл ажиллагааны бүх шатанд ашиглаж байна. Иймээс гэмт хэргийн статистикийг онол, арга зүйн талаас судалж, түүнийг боловсронгуй болгох, өргөн цар хүрээг хамарсан дүн шинжилгээ хийх шаардлага аливаа улсын хөгжлийн чиг хандлагыг даган бий болж байна.

“Гэмт хэргийн статистик зүй” гэдгийг шинжлэх ухааны үндэслэлтэй зохион байгуулсан програмаар, гэмт хэргийн талаарх тоо бүртгэл хөтлөх, цуглуулах, боловсруулах, түүнд судалгаа, шинжилгээ хийж гэмт хэргийн тоон мэдээллийг шалтгаан нөхцөл, шинж чанартай нь уялдуулан тодорхой орон зай, цаг хугацаанд судалдаг салбарын статистик хэмээн тодорхойлж болохоор байна.

Гэмт хэргийн статистикийн судлах үндсэн зүйл нь гэмт хэргийн гаралт, тархалт, бүтэц, хөдөлгөөн, гэмт хэргийн шалтгаан, нөхцөл, сэжигтэн, яллагдагч, хохирогч иргэн, байгууллага, нийгэм, эрх зүйн хор хохирол, үр дагавар, гэмт хэрэгтэй тэмцэх, урьдчилан сэргийлэх чиглэлээр төр, засаг, шүүх эрх мэдэл болон хууль сахиулах байгууллагын үйл ажиллагааны чиглэл өгөх, ажлын үр дүнд үнэлгээ өгч, тодорхой санал дүгнэлт боловсруулах явдал юм.

Санамсаргүй, тохиолдлын байдлаар илэрч байгаa нэгжүүдээс бүрдэх адил чанарын юмс, үзэгдлийн нийлбэр хэмжээг статистик олонлог гэнэ. Тэгвэл санаатай болон болгоомжгүй үйлдэгдсэн гэмт хэргийн нийлбэр нь гэмт явдлын олонлог болох юм. Олонлогийн аль нэг тогтвортой байдлаар илрэх шинж байдал буюу мөн чанарыг статистикийн зүй тогтол гэнэ.

Статистикийн олонлогийг бүрдүүлж байгаа нэгж бүр тодорхой агуулга бүхий мөн чанартай, төрх байдлыг харуулсан нийтлэг үзүүлэлтийг статистикийн онолд шинж тэмдэг гэж нэрлэдэг. Бүх төрлийн шинж тэмдгийг тооны болон чанарын шинж тэмдэг гэж нэрлэдэг. Шинжлэх ухааны үндэслэлтэй урьдчилан төлөвлөсөн тодорхой программын үндсэн дээр зохион байгуулалттайгаар тоо мэдээллийг цуглуулах ажлыг статистик ажиглалт гэнэ.

Гэмт хэргийн байдлыг статистикийн аргаaр судлан боловсруулахын тулд урьдчилан төлөвлөсөн тодорхой програмын дагуу зохион байгуулалттайгаар гэмт хэргийн талаарх тоо мэдээллийг цуглуулах үйл ажиллагааг статистик ажиглалт гэж ойлгож болно. Статистик ажиглалт явуулан гэмт хэргийн тоо мэдээллийг цуглуулах 4 үндсэн арга хэрэглэдэг. Энэ нь шууд биечлэн бүртгэх, баримтын арга, асуулгын арга, анкетын арга гэж хуваана.

1. Шууд биечлэн бүртгэх арга. Энэ нь гэмт хэргийн талаарх тоо мэдээллийг бүртгэхдээ ажиглалт хийж байгаа хүн өөрөө биечлэн тооцоолох, хэмжих, жигнэх зэрэг найдвартай тоо мэдээллийг олж авах явдал юм. ЭнэхүY аргаар ажиглалт явуулахад нэлээд хөдөлмөр зарцуулдаг.

2. Баримтын арга. Албан ёсны бичиг баримт, нотолгооноос мэдээллийг бүртгэн авахыг хэлнэ.

3. Асуулгын арга. Нэлээд түгээмэл дэлгэрсэн ажиглалт юм. Гэмт хэргийн 
талаар судлаачаас хүмүүстэй харилцан ярилцах, асуух замаар бүртгэхийг хэлнэ. Асуулга нь нийгэм, эдийн засгийн үзэгдэл, процессын талаарх үнэн зөв шуурхай мэдээллийг авахад бусад аргыг бодвол илүҮ давуу талтай байдаг.

4. Анкетын арга. Тусгайлан боловсруулсан хүснэгтийн дагуу тоо баримтыг нөхүүлэн бичүүлж авах арга юм. Тухайлбал, Гэмт хэргийн бүртгэлийн маягт нөхөж бичихэд дээрх аргуудыг хэрэглэж байгаа ба дараа нь цуглуулсан эдгээр мэдээлэлд боловсруулалт хийх ажлыг програм хангамжийг ашиглан хийж байна.

Гэмт явдлын нөхцөл байдал, төлөв, чиг хандлага, шалтгаан нөхцөл, мөн гэмт хэрэг үйлдсэн этгээд, гэмт хэргийн халдлагад өртсөн этгээдийн болон захиргааны зөрчлийн талаарх мэдээллийг статистикийн шинжлэх ухааны арга зүйд тулгуурлан оновчтой цуглуулж, боловсруулж, дүн шинжилгээ хийн, түүний үр дүнг криминологи, виктимологи, эрүүгийн эрх зүй, эрүүгийн процессын эрх зүйн шинжлэх ухаантай уялдуулан судалж, гэмт явдалтай үр дүнтэй тэмцэх зорилт тавигдана.

Гэмт хэргийн статистик гэдэгт гэмт хэргийн тоо бүртгэл хөтлөх, мэдээллийн сан бүрдүүлэх, мэдээллийн сангаaс статистик мэдээлийг боловсруулан гаргах, түүнд дүн шинжилгээ, анализыг практиктай уялдуулан үр дүнтэй хийж, үр дүнд бодлого, үйл ажиллагаандаа ашиглах үйл ажиллагаа хамаарагдана. Гэмт хэргийн статистик гээд бичихэд Монгол Улсын хэмжээнд үйлдэгдсэн бүх гэмт хэргийг хамруулах зорилт тавигддаг. Мөн хуульд заасан харьяаллын дагуу хууль сахиулах байгууллагын бүртгэж, шалгаж буй гэмт хэргийг бүгдийг хамруулах зорилт тавигдах учиртай. Эндээс ургаад Гэмт хэргийн статистикийг боловсронгуй болгох асуудал нь хууль сахиулах, хамгаaлах, хэрэгжүүлэх байгууллагуудын мэдээллийн нэгдсэн тогтолцоог оновчтой бүрдүүлэх, үйл ажиллагааг нь жигдрүүлэх, давхардлыг арилгах явдал юм.
Гэмт хэргийн статистикийн арга зүй гэдэг нь гэмт хэргийн бүтэц, динамик болон хамаарлын зүй тогтлыг судлахад чиглэгдсэн арга, аргачлалын тогтолцоо юм.

Гэмт хэргийн статистикийн эцсийн үр дүн бол Монгол Улсын хэмжээнд үйлдэгдсэн бүх гэмт хэргийг зөв арга зүйгээр бүртгэдэг, цуглуулдаг, нийтэд мэдээлдэг, Монгол Улсын төр засаг, иргэд, олон нийт гэмт хэргийн бодит нөхцөл байдлыг мэдэрч, түүнтэй тэмцэх төрийн бодлого, иргэдийн тэмцэл үр дүнд хүрэхэд оршино гэж дүгнэж болохоор байна.

Гэмт хэргийн статистик зүйн онол, хэрэглээтэй уялдаатай гэмт хэргийн дүн шинжилгээ, гэмт хэргийн компьютер статистик гэсэн ойлголт олон улсад байдаг.

Crime analysis буюу гэмт хэргийн дүн шинжилгээ гэдэг нь гэмт хэрэг, түүнтэй холбоотой мэдээ, мэдээлэл, аргын талаар мэдээлэл цуглуулах, гэмт хэргийг тайлбарлах, прогноз гаргах, хэв маягийг ялган таних, яам, агентлагийн тактикийн болон стратегийн төлөвлөгөөг бий болгох, гүйцэтгэлийг үнэлэх явдал юм. Гэмт хэргийн дүн шинжилгээ цагдаагийн байгууллагаас илүу тогтмол хэрэглэдэг болсон хэдий ч гэмт хэрэг судлах, цагдаагийн байгууллагад дэмжлэг үзүүлэхэд хэд хэдэн гэмТ хэргийн аналитик аргыг хэрэглэж байна. (Mamalian and LaVigne 1999)[17]

Компьютер статистик (Compstat)-ийг гэмт хэргийн дүн шинжилгээ, удирдлагын арга барилд өргөн хэрэглэгддэг. КомпСтатыг анх 1994 онд Нью-Йорк хотын цагдаагийн газар танилцуулж байсан. Хамгийн чухал нь КомпСтатыг олон янзаар, орчин үеийн цагдаагийн хэв журам сахиулах үйл ажиллагаанд чиглэсэн удирдлагын шинэчлэлийн хэрэглээ болсон байна. (Weisburd 2003, 427) [18].

Судлаач Д.Нямбатын орчуулж, бэлтгэсэн “Америкийн Бостоны террорист халдлага", “Өнгөлөг Албани”, “Удирдах ур чадвар”, “Гэмт хэрэгтэй тэмцэхэд статистик, мэдээллийн сангийн ач холбогдол" сэдэвт сургалтын кинонд АНУ-ын гэмт хэргийн 
гаралтаар нэгдүгээрт жагсаж, иргэд нь айдас хүйдэст автсан байсан Нью-Жерси мужийг хар жагсаалтаас гаргахад гэмт хэргийн статистик болон мэдээллийн санг Үүсгэх нь гэмт хэргээс урьдчилан сэргийлэх, тэмцэх, илрүүлэх үр дүнтэй арга мөн болох талаар өгүүлсэнээс үзэхэд гэмт хэргийн статистикийн ач холбогдлыг гадаадын зарим улсын түвшинд тодорхойлж байгаагийн илэрхийлэл мөн хэмээн үзэж байна.

\section{Гэмт хэргийн статистикийн тулгамдсан асуудал}

Монгол Улсадгэмтхэргийнстатистикийн тогтолцоо оновчтой бус, цагдаа, авлигатай тэмцэх, шүүхийн шийдвэр гүйцэтгэх, прокурор, шүүхийн байгууллагын гэмт хэрэг, зөрчлийн тоо бүртгэл, арга зүй уялдаагүй, гэмт хэрэг, зөрчлийн тоо бүртгэлийн аргачлал, статистик мэдээний нэгдмэл байдал хангагдахгүйгээс гэмт явдлын тоо бүртгэл бодитой бус байгаа нь төрөөс гэмт хэрэгтэй тэмцэх бодлогод үр дүнтэйгээр нөлөөлж чадахгүй. Түүнчлэн, гэмт хэргийн статистикийн онол, арга зүйн талаарх эрдэм шинжилгээний бүтээл хомс байна. Гадаад, дотоодын эх сурвалж, бүтээл, практикийг харьцуулан судлах замаар “Гэмт хэргийн статистик зүй” хэмээх хавсарга дундын шинжлэх ухаан хэмээн Үзэж, түүний онол, арга зүй, практикийг хөгжүүлэх шаардлага байна.

Засгийн газрын үйл ажиллагааны 2012-2016 хөтөлбөр, ХЗДХЯ-ны үйл ажиллагааны хөтөлбөрүүдэд цахим мэдээллйн тогтолцоог төрийн байгууллагуудын үйл ажиллагаанд нэвтрүүлэх, хүнд суртал, өргөдөл гомдолыг шийдвэрлэх олон шат дамжлагыг багасгах талаар тодорхой заалтууд туссан. Үүнийг хэрэгжүүлэхээр ХЗДХЯ-ны дэргэд мэргэжилтнүүдээ бүрдсэн төслийн баг 2013 оноос байгуулагдан хууль сахиулах байгууллагуудын цахим мэдээллийн нэгдсэн тогтолцоог бүрдүүлэхээр ажиллаж байна. Засгийн газрын 2012-2016 оны үйл ажиллагааны хөтөлбөрт “Захиргааны болон эрүүгийн зөрчлийг бүртгэх нэгдсэн сан бий болгож, эрсдэлийн удирдлагын менежментийг нэвтрүүлэх...” гэж заасан. Үүний дагуу хууль зүйн цахим мэдээллийн тогтолцоог шүүх эрх мэдлийн байгууллага болон хууль сахиулах байгууллагын хамтын ажиллагаагаар бий болгож, түүнийг хөгжүүлэх хүлээлт байна.

Түүнчлэн, хууль сахиулах болон шүүх эрх мэдлийн гэмт хэргийн статистикийн мэдээллийг шинжлэх ухааны үндэслэлтэй бодитой гаргаснаар гэмт хэрэгтэй тэмцэх талаар төрөөс баримтлах бодлого, үйл ажиллагаа оновчтой, үр дүн хэрэгжих нөхцөл бүрдэж, ард иргэдийн аюулгүй, амар тайван орчинд амьдрах нөхцөл, хүний эрх, эрх чөлөө хангагдах юм. Хууль зүйн салбарын шинэтгэлийн хүрээнд батлагдсан Эрүүгийн хууль, Зөрчлийн тухай хуулийг 2017 оны 7 дугаар сарын 1-нээс мөрдөж эхлэхтэй холбогдон гэмт хэргийн бүртгэлийн болон мэдээний маягтуудыг шинэчлэх шаардлага бий болох бөгөөд эдгээрийг шинжлэх ухааны үндэслэлтэй боловсруулах хэрэгцээ байна.

ХЗДХЯ-аас боловсруулж буй Гэмт хэрэг, зөрчлөөс урьдчилан сэргийлэх тухай хуулийн төсөлд гэмт хэрэг, зөрчлөөс урьдчилан сэргийлэх нэгдсэн бодлого боловсруулах, шүүх эрх мэдлийн болон хууль сахиулах байгууллагын мэдээллийн давхардлыг арилгах, иргэдэд шуурхай үйлчилгээ үзүүлэх зорилгоор хууль сахиулах, шүүх эрх мэдлийн байгууллага хамтран нэгдсэн мэдээлийн сан бүрдүүлж, ашиглах заалт тусгагдсан учир мэдээллийн сан бүрдүүлэх, статистик мэдээлэл эрхлэн гаргах үйл ажиллагааг шинжлэх ухааны үндэслэлтэй боловсронгуй болгох шаардлага байна.

Гэмт хэргийн статистикийн талаар онолын судалгаа хийж, судалгааны үндсэн дээр онолын үндэслэл боловсруулах, эрдэм шинжилгээний бүтээл ном эрхлэн гаргах, өгүүлэл нийтлүүлэх, цагдаа, авлигатай тэмцэх, прокурор, шүүх, шүүхийн шийдвэр 
гүйцэтгэх байгууллагын гэмт хэргийн бүртгэлийн болон статистикийн мэдээний маягтыг шинэчлэх, програм хангамж, мэдээллийн системийг нь боловсронгуй болгох санал боловсруулах, холбогдох баримт бичигт өөрчлөлт оруулах зэрэг тулгамдсан асуудал байна.

\section{Гэмт хэргийн статистикийн тогтолцооны өнөөгийн байдал}

Монгол Улсад гэмт хэргийн талаарх мэдээллийн сан бүрдүүлэх, статистикийн мэдээг шүүх, прокурор, цагдаа, авлигатай гүйцэтгэх байгууллагаас эрхлэн гаргаж, Үндэсний статистикийн хороонд нэгтгэж, улсын хэмжээний нийгэм, эдийн засгийн мэдээнд тусгаж байна. Эдгээр байгууллага тус тусын үйл ажиллагааны хүрээнд статистик мэдээллийг нийтийн хүртээл болгож, үйл ажиллагаанд ашигладаг. Дээрх хууль сахиулах зарим байгууллагын аймаг, нийслэл, дүүрэг, сум дахь нэгжийн гэмт хэргийн статистик мэдээ нь тухай нутаг дэвсгэрийн төрийн захиргааны статистикийн нэгжийн эрхлэн гаргаж буй статистикийн мэдээнд хамрагдаж байдаг. тэмцэх, тагнуул, шүүхийн шийдвэр

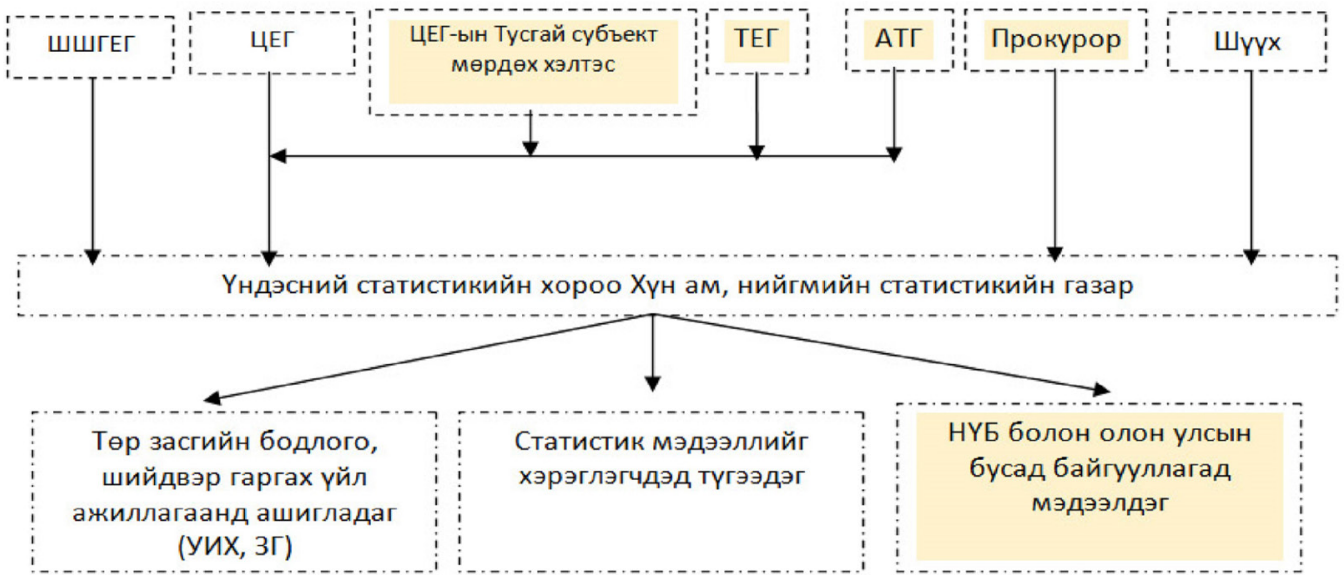

\section{Зураг-2. Гэмт хэргийн статистикийн тогтолиооны өнөөгийн байдал}

Монгол Улсад гэмт хэргийн статистикийн мэдээлэл эрхлэн гардаг тогтолцоо нь оновчтой бүрдээгүй хэмээн дүгнэж байна. Цагдаагийн байгууллагад бүртгэгдсэн гомдол, мэдээлэл, гэмт хэрэг, захиргааны зөрчил, Прокурорын байгууллага чиг үүргийн хүрээнд хяналт тавьсан эрүүгийн хэрэг, гомдол, мэдээлэл, Шүүхэд шийдвэрлэгдсэн хэрэг, Шүүхийн шийдвэр гүйцэтгэх байгууллагад шүүхийн шийдвэр гүйцэтгэлийн статистикийн мэдээллийг тус тус эрхлэн гаргадаг. Эдгээр статистик мэдээллийн анхан шатны бүртгэл болох бүртгэлийн маягт, мэдээний маягт нь харилцан адилгүй байдаг. Тагнуулын байгууллагын хувьд хуулиар харьяалуулсан гэмт хэрэг шалгаж, цагдаагийн байгууллагын мэдээллийн санд оруулдаг ч улсын хэмжээний гэмт хэргийн статистикийн мэдээнд тэр бүр тусгадаггүй. Авлигатай тэмцэх газар мөн хуулиар харьяалуулсан гэмт хэргийг бүртгэж, илрүүлж шалгадаг ба шалгаж буй гэмт хэргийн талаарх мэдээллийг цагдаагийн байгууллагын мэдээллийн санд бүртгүүлж, улсын хэмжээний мэдээнд тусгагдаг ч албаны нууцлал гэх үүднээс гэмт хэрэг бүрийг бүрэн мэдээллийн 
санд оруулдаггүй, статистикийн мэдээнд тусгахгүй явдал байна. Мөн ЦЕГ-ын Тусгай субъект мөрдөх хэлтэс (хуучнаар УЕПГ-ын Мөрдөх алба) харьяаллын дагуу шалгаж буй хэргийн талаарх мэдээллийг цагдаагийн байгууллагын мэдээллийн санд оруулдаг.

Сүүлийн 10 жилийн байдлаар Монгол Улсад жилд дунджаар 23 мянган гэмт хэрэг бүртгэгдэж байгаa боловч эрдэмтэн, судлаачдын судалгаa, таамаглалаар нуугдмал гэмт хэргийн түвшин өндөр байгааг дурдсан байдаг. Дэлхийн улсуудад нуугдмал гэмт хэргийн түвшин 2-25 дахин өндөр байдгийг шинжлэх ухааны үндэслэлтэй судлан гаргасан байдаг [19]. 2016 оны статистикийн мэдээллээр Цагдаагийн байгууллага 94324 нь гэмт хэргийн шинжтэй гомдол, мэдээлэл хүлээн авч, шалгаснаас 27167 гэмт хэрэг бүртгэгдсэн ба Авлигатай тэмцэх байгууллага 427 гэмт хэргийн талаарх гомдол, мэдээлэл шалгаснаас 83 нь эрүүгийн хэрэг үүсгэн шалгасан байна. Прокурорын байгууллага нь гэмт хэргийн талаарх 94751 гомдол, мэдээлэл хүлээн авч, шалгасан бол 29304 нь эрүүгийн хэрэг үүсгэн шалгасан ба 41525 эрүүгийн хэрэгт хэрэг бүртгэлт, мөрдөн байцаалтын ажиллагаа явуулжээ. Шүүхээс 5762 эрүүгийн хэргийг хянан шийдвэрлэж, 6566 хүнд ял шийтгэсэн статистикийн мэдээлэл гарсан байна.

Өнөөгийн байдлаар цагдаагийн байгууллагад гэмт хэрэг, зөрчлийн талаарх гомдол, мэдээлэл, гэмт хэрэг, гэмт хэрэгт холбогдсон этгээд, хохирсон иргэн, байгууллага, хохирол, захиргааны зөрчил, түүнийг үйлдсэн этгээдийн талаарх мэдээллийн сан улсын хэмжээнд онлайнаар бүрдэж, түүнээс статистикийн мэдээлэл боловсрогдож байна. Харин шүүх, прокурорын байгууллагын хувьд мэдээллийн сан бүрдүүлэх системээ хөгжүүлж эхэлж байгаа бөгөөд статистик мэдээлэл эрхлэн гаргах, үндэсний статистикийн мэдээлэлд тусгагдах үйл явц боловсронгуй бус байна.

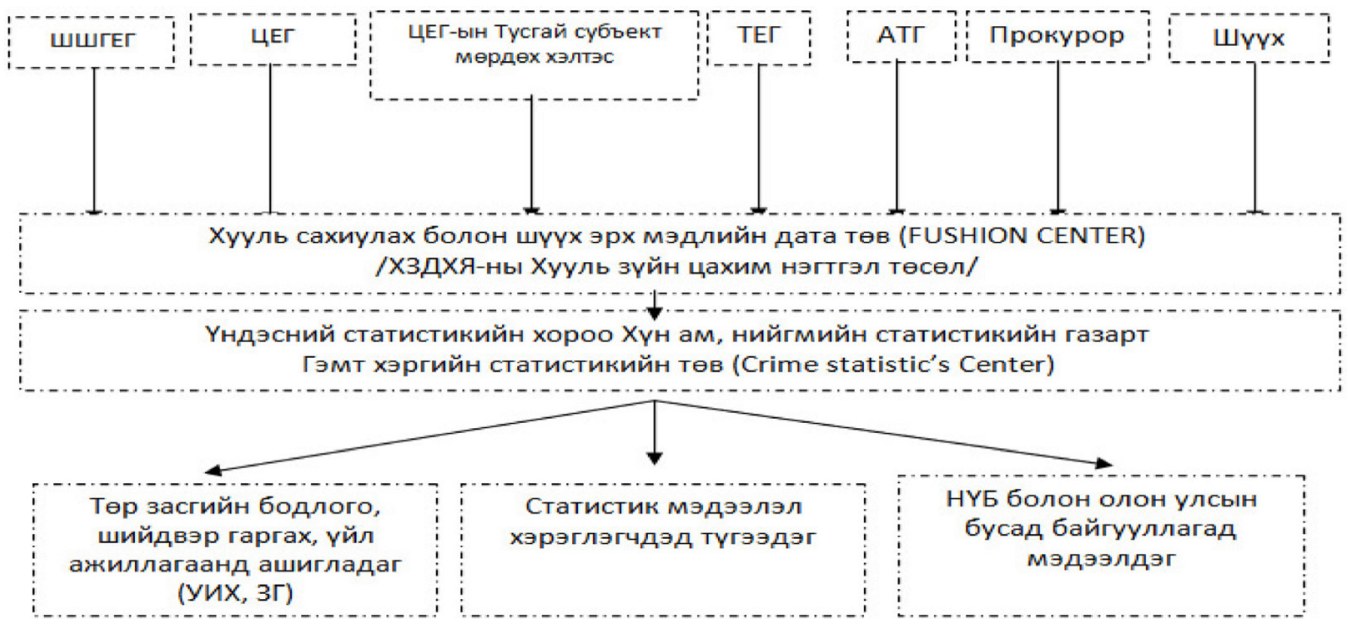

Зураг-3. Гэмт хэргийн статистикийн тогтолцооны загвар

Үндэсний статистикийн хорооны Хүн ам, Нийгмийн статистикийн газарт цагдаа, прокурор, шүүх, шүүхийн шийдвэр гүйцэтгэх байгууллагын гэмт хэргийн талаарх статистик мэдээлэл нэгтгэн гарч, улсын хэмжээний нийгэм, эдийн засгийн байдалд тусч, улмаар төр засгийн холбогдох байгууллага, албан тушаалтнуудын түвшинд танилцуулагдаж, НҮБ-ын статистикийн төв байгууллала зэрэг олон улсын байгууллагад хүргэдэг. Цаашид Монгол Улсын гэмт хэргийн 
статистикийн тогтолцоог боловсронгуй болгон төлөвшүүлэх, тухайлбал, хууль сахиулах, шүүх эрх мэдлийн байгууллагын мэдээллийн нэгдмэл байдлыг хангах, гэмт хэргийн статистикийн үндэсний хэмжээний гэмт хэргийн статистикийн аргачлал, эрх зүйн актыг бий болгож, мөрдүүлэх, гэмт хэргийн статистикийн үндэсний гэмт хэргийн мэдээллийн үзүүлэлтийг олон улсын жишиг үзүүлэлтэд нийцүүлэх, Үндэсний статистикийн хороонд гэмт хэргийн статистик мэдээлэл хариуцсан нэгж үйл ажиллагаа явуулах нь үр дүнтэй гэж судлаачийн хувьд үздэг.

\section{Гэмт хэргийн статистикийн эрх зүйн зохицуулалт}

Гэмт хэргийн статистик мэдээлэл эрхлэн гаргахад Монгол Улсын Үндсэн хууль, Статистикийн тухай, Цагдаагийн албаны тухай, Гэмт хэргээс урьдчилан сэргийлэх тухай, Прокурорын байгууллагын тухай, Шүүхийн тухай, Шүүхийн захиргааны тухай хуулийг мөрдөж байна.

Цагдаагийн байгууллагын хэмжээнд Монгол Улсад бүртгэгдсэн гэмт хэргийн тоо бүртгэл хөтлөх журам /ЦЕГ-ын даргын 2015 оны A/21 дүгээр тушаалаар баталсан/, Прокурорын байгууллагын мэдээлэл, мэдээллийн системийн аюулгүй байдлыг хангах журам /Монгол Улсын Ерөнхий Прокурорын 2014 оны A/03 дугаар тушаалаар баталсан/, Гэмт хэргийн тоо бүртгэлийн маягтыг нөхөх, мэдээллийн санд төвлөрүүлэх журам/ АТГ, ТЕГ, ЦЕГ, УЕП-Ын дэргэдэх МБА-ны даргын хамтарсан 2010 оны 43/182/223/21 дүгээр тушаалаар баталсан/, Шүүхийн статистикийн мэдээлэл, тайлан гаргах журам /Монгол Улсын Шүүхийн ерөнхий зөвлөлийн 2006 оны 17 дугаар тогтоолоор батлагдсан/, “Салбарын статистик мэдээллийн сан бүрдүүлэх, эрхлэн хөтлөх” /Хууль зүйн сайдын 2014 оны А/48 дугаар тушаалаар баталсан/ журам зэрэг эрх зүйн зохицуулалтын хүрээнд зохицуулагдаж байна.
Монгол Улсад сүүлийн 10 жилд гэмт хэргийн улмаас төр засаг, иргэн, аж ахуйн нэгж, байгууллагад нийт 400 тэрбум төгрөгийн эд материалын хохирол учирч, нийт 16 мянган иргэн нас барж, нийт найман мянган хүн хөнгөн, хүндэвтэр, хүнд хэлбэрээр гэмтсэн байгаа нь Монгол Улсын Үндсэн хуулийн 19 дүгээр зүйлийн 19.1-д “Төрөөс хүний эрх, эрх чөлөөг хангахуйц эдийн засаг, нийгэм, хууль зүйн болон бусад баталгааг бүрдүүлэх, хүний эрх, эрх чөлөөг зөрчихтэй тэмцэх, хөндөгдсөн эрхийг сэргээн эдлүүлэх үүргийг иргэнийхээ өмнө хариуцна" гэсэн заалтын хэрэгжилтийг хэмжих хэмжүүр үзүүлэлт юм.

Гэмт хэргээс урьдчилан сэргийлэх тухай хуулийн 3 дугаар зүйлд “Гэмт хэргээс урьдчилан сэргийлэх ажил”-ыг, мөн зүйлийн 3.1 дэх хэсэгт “Гэмт хэргээс урьдчилан сэргийлэх ажил нь гэмт хэргийн тухай мэдээллийг судалсны үндсэн дээр гэмт хэрэг гарч байгаа шалтгаан нөхцөлийг тогтоох, арилгах, гэмт хэргээс урьдчилан сэргийлэх, таслан зогсоох талаар авч хэрэгжүүлж байгаа цогцолбор арга хэмжээ мөн” гэж тодорхойлсон нь гэмт хэргийн талаарх мэдээлэл цуглуулж, боловсруулалт хийж, дүн шинжилгээ хийх үйл ажиллагааны үндсэн эрх зүйн зохицуулалт агуулагдаж байгаа юм.

Мөн хуулийн 5 дугаар зүйл (Гэмт хэргээс урьдчилан сэргийлэх ажлын үндсэн чиглэл)-ийн 5.1 дэх хэсэгт “Гэмт хэргээс урьдчилан сэргийлэх ажлыг дараах үндсэн чиглэлээр зохион байгуулж хэрэгжүүлнэ” гэсний 5.1.1-д “гэмт хэргийн талаарх мэдээллийг цуглуулж, судалгаa, дүн шинжилгээ хийх замаар түүний гарч байгаа шалтгаан нөхцөлийг тогтоох", мөн хуулийн 20 дугаар зүйл (Гэмт хэргийн талаарх мэдээлэл цуглуулах, боловсруулах)ийн 20.1 дэх хэсэгт “Шүүх, прокурор, цагдаагийн болон хэрэг бүртгэх, мөрдөн байцаах, эрх бүхий бусад байгууллага нь гэмт хэргийн шалтгаан нөхцөлийг тогтоох зорилгоор гэмт хэргийн мэдээлэл цуглуулах, боловсруулах үйл ажиллагааг 
дараахь байдлаар эрхэлнэ:, 20.1.1.гэмт хэргийн тоо бүртгэл хөтлөх; 20.1.2.гэмт хэргийн мэдээллийг боловсруулж, дүн шинжилгээ хийх...”, 20.2 дахь хэсэгт “Дээр дурдсан байгууллагуудаас гэмт хэргийн талаар гаргах статистикийн мэдээллийн уялдуулсан маягт, журмыг тухайн байгууллагуудтай зөвшилцөн Үндэсний статистикийн газар батална" гэж заасан нь Монгол Улс дахь гэмт хэргийн статистикийн эрх зүйн үндсийг тодорхойлж байна.

Монгол Улсын хэмжээнд хууль сахиулах байгууллагад бүртгэгдэн, шалгагдаж буй

\section{ДҮГНЭЛТ}

“Гэмт хэргийн статистик” гэдэгт гэмт хэргийн тоо бүртгэл хөтлөх, мэдээллийн сан бүрдүүлэх, мэдээллийн сангаас статистик мэдээллийг боловсруулан гаргах, түүнд дүн шинжилгээ, анализыг практиктай уялдуулан үр дүнтэй хийж, үр дүнд бодлого, үйл ажиллагаандаа ашиглах үйл ажиллагаа хамаарагдана. Зохиолч, түүхч Херберт Жорж Уэльс нь: “Статистик нь нэг л өдөр уншиж, бичиж сурахтай адил зайлшгүй хэрэгцээтэй болно” хэмээн хэлсэн байдаг. / Herbert George Wells

(1886-1946)/.Гэмт хэргийн статистикийн эцсийн үр дүн бол Монгол Улсын хэмжээнд үйлдэгдсэн бүх гэмт хэргийг зөв арга зүйгээр цуглуулдаг, бүртгэдэг, нийтэд мэдээлдэг, түүнд үндэслэн гэмт хэрэгтэй тэмцэх төрийн бодлого үр дүнд хүрнэ хэмээн дүгнэж болохоор байна.

Гэмт явдал судлал, эрүүгийн болон эрүүгийн процессын эрх зүй, шинжлэн магадлахуй, шүүхийн шийдвэр гүйцэтгэх, цагдаагийн эрх зүй, криминалистик, математик, магадлал, статистик, социологи, мэдээллийн технологи зэрэг шинжлэх

\section{САНАЛ, ЗӨВЛӨМЖ}

\section{Нэг. Тогтолцоог боловсронгуй болгох}

1. Гэмт хэргийн статистикийн тогтолцоог боловсронгуй болгон төлөвшүүлэх, хууль гэмт хэрэг “Монгол Улсад бүртгэгдсэн гэмт хэргийн тоо бүртгэлийн заавар"-аaр цагдаагийн байгууллагын мэдээллийн сан бүрдэж байгаa нь эрх зүйн зохицуулалт, тогтолцооны хувьд учир дутагдалтай байна.

Цаашид гэмт хэргийн статистикийн үйл ажиллагааг зохицуулсан эрх зүйн орчинг боловсронгуй болгох, холбогдох хууль тогтоомжид нэмэлт, өөрчлөлт оруулах, гэмт хэргийн статистикийн үндэсний хэмжээний аргачлалыг бий болгож, мөрдүүлэх, гадаад орны эрх зүйн зохицуулалтыг харьцуулан судлах зайлшгүй шаардлага гарч байна.

ухаантай уялдаатайгаар гэмт хэргийн статистик зүйг судалж, улмаар хавсарга шинжлэх ухаан хэмээн Үзэж, түүнийг судалж, боловсронгуй болгох зайлшгүй шаардлага байна.

Гэмт хэргийн статистик зүйн онол, арга зүйг хөгжүүлснээр цагдаа, авлигатай тэмцэх, шүүхийн шийдвэр гүйцэтгэх, прокурор, шүүхийн байгууллагын гэмт хэргийн маягт, арга зүй боловсронгуй болоход дөхөмтэй болох юм.ТҮүнчлэн гэмт хэргийн талаарх статистикийн мэдээллийн нэгдмэл байдал, уялдаа холбоо хангагдаж, үнэн бодиттой статистик мэдээллийн үндсэн дээр гэмт хэрэгтэй тэмцэх, урьдчилан сэргийлэх төрийн бодлого оновчтой хэрэгжих нөхцөл бүрдэнэ. Түүнчлэн, эрүүгийн нөхцөл байдлыг тоон үзүүлэлтээр үнэн зөв, бодитой илэрхийлэх, дүн шинжилгээ хийж, урьдчилан сэргийлэх ажлын үр дүн дээшлэх нөхцөл бүрдэхийн зэрэгцээ гэмТ явдлын шалтгаан, нөхцөлийг оновчтой тодорхойлж, хариу авах арга хэмжээг хэрэгжүүлэх ач холбогдолтой болох юм.

сахиулах, шүүх эрх мэдлийн байгууллагын мэдээллийн нэгдмэл байдлыг хангах, (Зураг-3. Гэмт хэргийн статистикийн 
тогтолцооны загвар)

2. Гэмт хэргийн статистикийн үндэсний хэмжээний гэмт хэргийн статистикийн аргачлалтай холбогдсон эрх зүйн актыг бий болгох, мөрдүүлэх

3. Гэмт хэргийн статистикийн үндэсний гэмт хэргийн мэдээллийн ҮзҮҮлэлтийг НҮБ-ын жишиг үзүүлэлтэд нийцүүлэх

4. Үндэсний статистикийн хороонд гэмт хэргийн статистикийн мэдээлэл хариуцсан нэгжийг байгуулах

Хоёр. Онол, арга зүйг судалж, хөгжүүлэх

1. Гэмт хэргийн статистик зүйг онолын түвшинд судалж, арга зүйн үндэслэлийг боловсруулах, аргачлал, зөвлөмж, стандарт, гарын авлага, сурах бичиг боловсруулан сургалтанд нэвтрүүлэх;

2. Хууль сахиулахын их сургууль, түүнчлэн хууль зүйн их, дээд сургуулийн бакалавр, магистр, докторын сургалтын төлөвлөгөө, хөтөлбөрт гэмт хэргийн статистикийн үндэс-I, гэмт хэргийн статистикийн судалгааны арга зүйн хэрэглээ-II, гэмт хэргийн статистикийн дүн шинжилгээ-III хичээлийг залгамж холбоотойгоор оруулах

\section{Гурав. Хүний нөөцийг сургах, мэргэшүүлэх}

1. Цагдаа, авлига, шүүхийн шийдвэр, прокурор, шүүхийн байгууллагад гэмт хэргийн статистикийн чиглэлээр ажиллах хүний нөөцийг бэлтгэх асуудлыг ХЗДХЯ, БСШУСЯ-аас бодлогоор дэмжлэг үзүүлж, ХСИС-иас хамтарсан хөтөлбөрөөр бэлтгэж эхлэх

2. Хууль сахиулах болон шүүх эрх мэдлийн байгууллагын ажилтан, хууль сахиулагч, хуульчдын статистикийн мэдлэг, ур чадвар, хэрэглээг дээшлүүлэх зорилгоор богино хугацааны сургалтыг үе шаттайгаар явуулах

\section{Дөрөв. Гэмт хэргийн статистикийн мэдээллийн түгээлтийг боловсронгуй болгох}

1. Гэмт хэргийн цагаан номыг гадаад орнуудын жишгийн дагуу эрхлэн гаргах

2. Хууль сахиулах, шүүх эрх мэдлийн байгууллага, Үндэсний статистикийн хороо гэмт хэргийн статистикийн мэдээлэл, танилцуулгыг цахим хуудаст англи, монгол хэлээр байршуулж, статистикийн мэдээллийг хэрэглэгчдэд $\quad$ хүртээмжтэй байдлаар хүргэх үйл ажиллагааг сайжруулах

\section{HOM 3YЙ}

1. Болдбаатар, Ж. Нямдаваа, О. Криминологи. УБ. 2010. 5 дахь тал

2. Жаниан, Н. Криминологи. УБ. 2004. 8 дахь тал

3. Jack R. Greene, The Encyclopedia Police Science, Third Edition. 2007

4. Jack R. Greene, The Encyclopedia Police Science, Third Edition. 2007

5. Нарангэрэл, С. Эрх зүйн эх толь бичиг. 2008

6. Монгол Улсын Үндсэн хууль, “Төрийн мэдээлэл” эмхтгэлийн 1992 оны 1 дүгээрт нийтлэгдсэн,

7. Энхболд, Б. Хотжилт ба гэмт явдал. УБ. 2011

8. Нямсүрэн, Ч. Гэмт хэргийн виктимологи. УБ. 2005

9. Эрдэнэсувд, Л. Бизнесийн статистик. УБ. 2004. 6 дахь тал

10. Кручкин, Ю. Орос-Монгол-Монгол-Орос орчин үеийн хэлний дэлгэрэнгүй толь бичиг. Москва хот. 2006. 496

11. БНМАУ-ын Шинжлэх Ухааны Академийн Хэл зохиолын хүрээлэн, Цэвэл.Я, Монгол хэлний товч тайлбар толь. УБ. 1966. 541 дэх тал

12. Эрдэнэсувд, Л. Бизнесийн статистик. УБ. 2004. 9 дэх тал

13. Энхбат, Р. Магадлалын онол, математик статистикийн гарын авлага. УБ. 2002

14. ХСИС-ийн Эрдэм шинжилгээ, хөгжлийн хүрээлэнгийн Цагдаа судлалын төв. Цагдаагийн шинжлэх ухааны зарим нэр томьёоны гарын авлага /Jack R. Greene, The Encyclopedia Police Science. Third Edition. 2007. I (A-I index), II (J-Z index)/, УБ. 2016 
15. ХСИС-ийн Эрдэм шинжсилгээ, хөгжлийн хүрээлэнгийн Цагдаа судлальн төв. Цагдаагийн шинжлэх ухааны зарим нэр томьёоны гарын авлага /Jack R. Greene, The Encyclopedia Police Science. Third Edition. 2007, I (A-I index), II (J-Z index)/, УБ. 2016

16. Болдбаатар,Ж. Нямдаваа, О. Криминологи. УБ. 2010

17. http://hakusyo1.moj.go.jp/en/nendo nfm.html

18. http://legalinfo.mn/law/details/50?lawid $=50$

19. https://mn.wikipedia.org

20. http://chandra_b.blog.gogo.mn/read/entry434220 


\title{
THEORETICAL AND PRACTICAL ISSUES CONCERNING CRIME STATISTICS
}

\author{
Munkhdorj.B
}

Research and Development Institute of Law Enforcement University of Mongolia

E-mail:b.munkhdorj@gmail.com

"Crime Statistics" can be defined as a sectorial statistical data as it exhibits the reasons and causes of crime in relation to the timeframe and place of incidence, which are all registered in a specialized software program that maintains registration, collection, data processing and analysis. The practical use of this is of special importance.

The crime statistics system in Mongolia is defective as the police, anti-corruption agency, prosecutor's office and courts produce statistical data which are not integrated and unrealistic. Its methodology is also unscientific. This makes it ineffective for influencing government policies.

Accordingly, this means that there are various problems that need to be considered such as conducting theoretical research on crime statistics; developing the theories and concepts of crime statistics based upon scientific research; publishing research works and articles; renewing the registration forms used by the police, anti-corruption agency, prosecutor's office and courts; proposing recommendations for enhancing the software programs and information systems used by state agencies; and renewing the appropriate documents.

Moreover, there are also additional requirements of improving the legal environment for crime statistics; making amendments to domestic laws and statutes if required; developing and using a national methodology for registration of crime; and conducting comparative studies of foreign countries where the regulations, standards and decisions are studied. This article views crime statistics as an applied science, providing an overall evaluation of crime statistics in Mongolia and proposes the appropriate recommendations for improving the system.

Keywords: Statistics, crime, criminology, crime statistic's; 